\title{
COMPANY VALUE ANALYSIS BASED ON INTELLECTUAL CAPITAL MEDIATED BY FINANCIAL PERFORMANCE Study on LQ 45 Companies in Indonesia Stock Exchange 2015-2019 Period
}

\author{
Puja Firmasari ${ }^{1)}$, Rike Setiawati ${ }^{2)}$, Fitriati ${ }^{3)}$ \\ ${ }^{1,2,3)}$ Faculty of Economic and Business Jambi University, Jambi, Indonesia \\ Corresponding author: rike_setiawati@unja.ac.id
}

\begin{abstract}
Price book value is an indicator of company value that is usually used as an assessment by investors in investing. This study aims to obtain the results of the study of the influence of Intellectual capital on firm value with indicators of value-added intellectual capital (VAIC) and financial performance as intervening variables and size, age, and leverage as controllers in LQ 45 companies listed on the Indonesian Stock Exchange (IDX). The method used is purposive sampling resulting in a sample of 29 companies-data analysis using the Partial Least Square (PLS) tool. The results show that the influence of intellectual capital on firm value is not directly but fully mediated by financial performance. The financial performance generated through the proper management of intellectual capital is a significant concern for investors in assessing the company.
\end{abstract}

Keywords: Intellectual Capital, Firm Value, Financial Performance

\section{Introduction}

Human resources who are intelligent and have the ability, skills, and commitment are needed to support improving company performance. The resources contained in the company do not only include tangible assets but also include intangible assets or are included in company resources (Alipour, 2012). Intangible assets using intellectual capital (IC), which have the potential to create a competitive advantage and longterm value, are more important and efficient than tangible assets (Al-Musali et al., 2014)

The company has the goal of optimizing the company's value, which is used as a benchmark by investors in assessing the company; if the company has a high share price in the eyes of investors, the company's value will also be increased. However, it is not only the stock price that can increase the company's value. Nuryaman (2015) states that firm value is an investor's perception of the company, which is often associated with the company's market performance. Market performance is a measure of company performance that combines investment returns and company risk. Price book value (PBV) is used as an analytical tool for investors in assessing the performance of stock prices with book values.

Handayani (2015) provides an assessment that Intellectual capital that has been used efficiently will increase market value. Zéghal \& Maaloul (2010) stated that measuring intellectual capital is very difficult. The high level of difficulty in identifying, measuring, and disclosing causes them not to be included in the balance sheet/financial report (Puspitosari, 2016). In addition, it is no secret that the balance sheet does not attempt to provide the company's actual value; on the contrary, it is only prepared for reporting purposes (Ozkan et al., 2016). Whereas financial statements have a decision-making function for stakeholders to make economic decisions. However, financial reporting has limitations in explaining non-physical assets to show intellectual capital. Therefore, financial statements must reflect the existence of intangible assets and the amount of value recognized (Nunki et al., 2014).

Intellectual capital (IC) as an intangible asset of knowledge and information resources in a company that is used to create advantages and added value (William, 2001). IC is defined by Pulic (1998) to obtain added value as a result of the company's intellectual property with a Value added intellectual coefficient (VAIC) method. This method consists of three main categories within the company, namely Human Capital (HC), Structural Capital (SC) and Capital Employed (CE).

Financial performance in this study serves as an intervening variable as another factor that contributes to increasing firm value not only from intangible assets but also from tangible assets, the company's financial performance is measured using Return On Assets (ROA), Return On Equity (ROE) and Net Profit Margin (NPM).

From the research gap on intellectual capital in general, financial companies obtained positive results such as (Joshi et al., 2012), (NP Tran \& Vo, 2020) and (Al-Musali et al., 2014) the ability of Saudi banks to create value is very dependent on IC. (Puspitosari, 2016), (Nunki et al., 2014) and (Natalia, 2014) provides a significant influence between all variable indicators. In addition, intellectual capital research was also conducted on industrial companies such as Sardo \& Serrasqueiro (2018) on manufacturing companies in Europe, showing that IC can increase firm value and financial performance of European companies. Kurniawan et al. (2020), Nuryaman (2015) and Baroroh, (2013) there is an influence for manufacturing companies on the company's current and future performance. 
Meanwhile, other studies show the negative influence of intellectual capital on firm value and financial performance such as research conducted by Angraini et al. (2020) and Lestari \& Sapitri (2016) on Indonesian manufacturing companies in 2010-2013 and analysis by Binh and Hong in The banking sector in Thailand 2018 show that there is an insignificant positive relationship between Intellectual Capital on financial performance indicators, besides that Chowdhury et al., (2018) who examined textile sector companies in Bangladesh stated that the empirical study failed because there was no positive relationship and Intellectual Capital in the textile industry in Bangladesh.

Research on the LQ 45 company is reasonable because the company is considered to have stocks with high liquidity and market capitalization and is supported by good company fundamentals. Based on this assumption, the LQ 45 company already has good fundamentals, so investors are interested in the company. Although incorporated in an LQ 45 company, this does not guarantee that the company has a strategy to achieve a competitive advantage. To achieve this, of course, it cannot be separated from the development of technology and knowledge of human resources to continue to innovate. As help is needed by LQ 45 companies to create an innovation with a concept to make a decision.

\section{Research Methods}

The subjects in the study were LQ 45 companies listed on the Indonesia Stock Exchange for the 2015 2019 period. The dependent variable used is company value with price-book (PBV) indicators. In contrast, the independent variable is Intellectual Capital with VAIC (value-added intellectual capital) indicators, namely HCE (human capital efficiency), SCE (structural capital efficiency), and CEE (capital empowered). efficiency) while intervening is financial performance, namely ROA (return on assets), ROE (return on equity), and NPM (net profit margin). Determination of the sample using the Purposive Sampling method with the criteria of LQ 45 companies listed and publishing financial statements on the Indonesia Stock Exchange and experiencing profits during the 2015-2019 period, from 45 companies, 27 companies were obtained that met the criteria with a total of 135 company data. The data sources were obtained from sample company financial statements from the Indonesia Stock Exchange (IDX) as secondary data. The tools used to assist in data analysis are using SmartPLS software version 3.2.9.

\section{Result and Discussion}

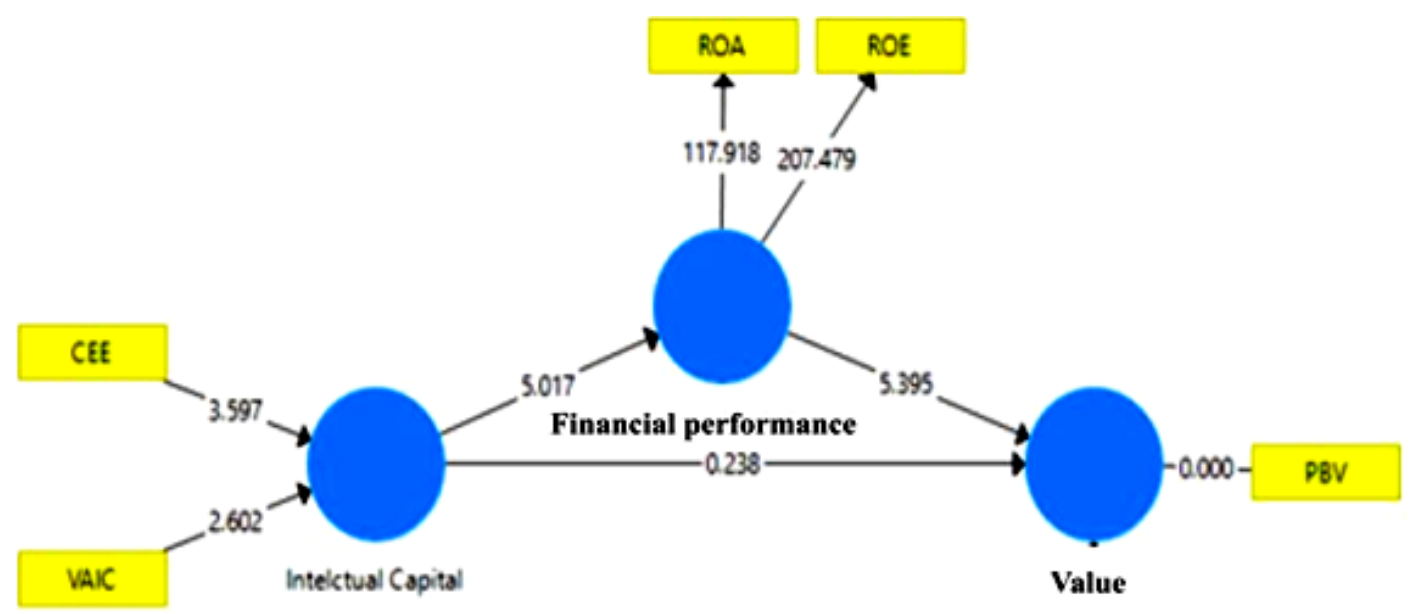

Figure 1. Research Model (Bootstrapping)

Table 1. Assessment of Direct Effects

\begin{tabular}{lccccc}
\hline & $\begin{array}{c}\text { Original } \\
\text { Sample } \\
(\mathrm{O})\end{array}$ & $\begin{array}{c}\text { Sample } \\
\text { Mean } \\
(\mathrm{M})\end{array}$ & $\begin{array}{c}\text { Standard } \\
\text { Deviation } \\
(\text { STDEV })\end{array}$ & $\begin{array}{c}\text { T Statistics } \\
(\mid \mathrm{O} / \mathrm{STDEV})\end{array}$ & P Values \\
\hline $\begin{array}{l}\text { Intelctual Capital -> } \\
\text { Financial Performance }\end{array}$ & 0,710 & 0,734 & 0,142 & 5,017 & 0,000 \\
\hline $\begin{array}{l}\text { Intelctual Capital -> } \\
\text { Company Value }\end{array}$ & $-0,048$ & $-0,045$ & 0,203 & 0,238 & 0,812 \\
\hline $\begin{array}{l}\text { Financial Performance } \\
->\text { Company Value }\end{array}$ & 0,908 & 0,914 & 0,168 & 5,395 & 0,000 \\
\hline
\end{tabular}


Table 2. Assessment of Indirect Effects

\begin{tabular}{lccccr}
\hline & $\begin{array}{c}\text { Original } \\
\text { Sample } \\
(\mathrm{O})\end{array}$ & $\begin{array}{c}\text { Sample } \\
\text { Mean } \\
(\mathrm{M})\end{array}$ & $\begin{array}{c}\text { Standard } \\
\text { Deviation } \\
(\text { STDEV })\end{array}$ & $\begin{array}{c}\text { T Statistics } \\
(\mid \mathrm{O} / \mathrm{STDEV})\end{array}$ & P Values \\
\hline $\begin{array}{l}\text { Intelctual Capital -> } \\
\begin{array}{l}\text { Financial Performance- } \\
>\text { Company Value }\end{array}\end{array}$ & 0,645 & 0,675 & 0,208 & 3,093 & 0,002 \\
\hline
\end{tabular}

The direct and indirect effect t-statistic tests were used to see the direct and indirect effects. As shown in Figures 1 and Tables 1 and 2, it is known that intellectual capital does not have a direct influence on firm value ( $\mathrm{t}$-statistic 0.238; p-value 0.812>0.05), but it is known that intellectual capital has a positive and significant effect on financial performance ( $\mathrm{t}$-statistical 5.017; p-value $0.000<0.05)$ and financial performance also has a positive and significant impact on firm value t-statistic 5.395; (p-value $0.000<0.05$ ). Furthermore, from the indirect effect assessment, it is known that intellectual capital has a positive and significant influence on firm value ( $\mathrm{p}$-value $0.002<0.05$ ). This indicates that to increase the value of the company, the financial performance must be better.

Intellectual capital cannot be directly involved in increasing the price book value (PBV). It can be interpreted that in looking at market value, investors do not really consider the knowledge of existing resources within the company, but performance is a direct assessment indicator. This is in line with the research results by Lestari \& Sapitri (2016), which states that the Value added intellectual coefficient does not affect firm value.

The study results interpret the importance of intellectual capital in improving company performance. This is illustrated by the management's ability to manage human resources, an essential part of an LQ 45 company that can optimize intellectual ability in creating added value to improve financial performance and ensure sustainable success in the future. These results support the research findings of Ozkan et al. (2016), Natalia (2014), Sardo \& Serrasqueiro (2018), which state that intellectual capital has a very close relationship with financial performance. In other words, companies can manage and develop their knowledge resources to increase their profits. Then the LQ 45 company has utilized intellectual capital efficiently and effectively in achieving competitive advantage and has influenced the company's efforts to increase revenue.

The performance reflected by the high ROA, ROE, and NPM as a result of capital management invested by investors effectively and efficiently can generate company profits and have a good impact on PBV. Investors will give a higher assessment to companies with higher financial performance, and the increased financial performance will be responded to positively by the market, thereby increasing the company's value. These results also support Nuryaman's (2015) research, which states that financial performance positively affects firm value.

Furthermore, to interpret the indirect effect of this research, that the LQ 45 company has been able to empower the expertise, knowledge of human resources in absorbing information, technology, and intellectuality of its employees in creating added value that will improve company performance, marked by good CEE and VAIC values as Intellectual capital indicator. Furthermore, the company's performance will create corporate value as reflected by ROA, ROE, and NPM. Therefore, financial performance becomes a benchmark for intellectual capital that will increase the company's value. The results of this study prove that financial performance as an intervening variable is able to mediate the relationship between intellectual capital and firm value. These results are supported by Nuryaman's research (2015). Nunki et al. (2014) companies that can manage intellectual capital well will improve their financial performance, and the implication is that the company's value will also increase. This means that knowledge resources play an essential role in achieving ever-increasing profits; the market will also give a higher value to the company.

\section{Conclusion}

LQ 45 company has managed intellectual capital well to improve financial performance. However, intellectual capital has not been proven to be a benchmark for investors in assessing the company. However, indirect financial performance can act as a complete mediation, increasing company value. Financial performance is still the main factor in determining the company, and investors are more interested in seeing financial performance because the company has managed intellectual capital well.

\section{References}

Al-musali, M. A. K., Nor, K., \& Ku, I. (2014). Intellectual capital and its effect on the financial performance of banks : Evidence from Saudi Arabia. Procedia - Social and Behavioral Sciences, 164(August), 201-207 https://doi.org/10.1016/j.sbspro.2014.11.068

Alipour, M. (2012). The effect of intellectual capital on firm performance: An investigation of Iran insurance companies. Measuring Business Excellence, 16(1), 53-66. https://doi.org/10.1108/13683041211204671

Angraini, F., Seprijon, Y. P., \& Rahmi, S. (2020). Pengaruh Intellectual Capital Terhadap Nilai Perusahaan dengan financial Distres sebagai Variabel Intervening. 15(2), 169- 190. 
Baroroh, N. (2013). Analisis Pengaruh Modal Intelektual Terhadap Kinerja Keuangan Perusahaan Manufaktur Di Indonesia. Jurnal Dinamika Akuntansi, 5(2), $172-182$. https://doi.org/10.15294/jda.v5i2.2997

Chowdhury, L. A. M., Rana, T., Akter, M., \& Hoque, M. (2018). Impact of intellectual capital on financial performance: evidence from the Bangladeshi textile sector. Journal of Accounting and Organizational Change, 14(4), 429-454. https://doi.org/10.1108/JAOC-11-2017-0109

Handayani, I. (2015). Pengaruh Modal Intelektual Terhadap Nilai Perusahaan Manufaktur Yang Terdaftar. EJurnal Katalogis, 3(9), 21-30.

Hermawan, S. (2019). Intellectual Capital, Financial Performance and Market Performance: Evidence From High IC Intensive Company in Indonesia. 11(2), 98- 107.

Hery. (2016). Analisis Laporan Keuangan. PT. Grasindo.

josep, F.Hair, J., G, Thomas, M. H., Cristian, M., R., \& Marko, S. (2017). A Primer On Partial Least Squares Struktural Equation Modeling (PLS-SEM) (second edi).

Joshi, M., Cahill, D., Sidhu, J., \& Kansal, M. (2012). Intellectual capital and financial performance: An evaluation of the Australian financial sector. Journal of Intellectual Capital, 14(2), 264-285. https://doi.org/10.1108/14691931311323887

Kurniawan, Y. I., Lukman, H., \& Tarumanagara, U. (2020). PENGARUH INTELLECTUAL CAPITAL TERHADAP FIRM VALUE DENGAN CAPITAL STRUCTURE SEBAGAI. 2, 971-981.

Lestari, N., \& Sapitri, R. C. (2016). Pengaruh Intellectual Capital Terhadap Nilai Perusahaan. Jurnal Akuntansi, Ekonomi Dan Manajemen Bisnis, 4(1), 28-33.

Mulyati, Sri; Lestari, R. N. (2015). Pengaruh Kinerja Keuangan Terhadap Nilai Perusahaan Manufaktur Makanan dan Minuman yang Terdaftar di Bursa Efek Indonesia.

Muthmainnah, A., Ali, M., \& Reni, A. (2020). Analisis Pengaruh Intellectual Capital terhadap Keputusan Investor (Studi pada Perusahaan Asuransi yang Terdaftar di Bursa Efek Indonesia). Hasanuddin Journal of Applied Business and Entrepreneurship, 3(1), 73-81. https://doi.org/10.26487/hjabe.v3i1.298

Narimawati, U., Sarwono, J., Affandy, A., \& Priadana, S. (2020). Ragam Analisi dalam metode Penelitian. CV Andi Offset.

Natalia, S. S. I. G. (2014). Pengaruh Modal Intelektual Terhadap Kinerja. 26(1),

Nunki, C., Sudibya, A., Mitha, M. I., \& Restuti, D. (2014). Jurnal Manajemen dan Bisnis Pengaruh Modal Intelektual Terhadap Nilai Perusahaan Dengan Kinerja Keuangan Sebagai Variabel Intervening. BENEFIT Jurnal Manajemen Dan Bisnis, 18(1), 14-29.

Nuryaman. (2015). The Influence of Intellectual Capital on The Firm 's Value with The Financial Performance as $\quad$ Intervening 292-298. https://doi.org/10.1016/j.sbspro.2015.11.037

Ozkan, N., Cakan, S., \& Kayacan, M. (2016). Intellectual capital and financial performance: A study of the Turkish Banking Sector. Borsa Istanbul Review, 17(3), 190-198. https://doi.org/10.1016/j.bir.2016.03.001

Pulic, A. (2000). VAICTM - An Accounting Tool for Intellectual Capital Management.

International Journal Technology Management, 20(5/6/7/8), 702-714.

Puspitosari, I. (2016). Pengaruh Modal Intelektual terhadap Kinerja Keuangan pada Sektor Perbankan The Impact of Intellectual Capital on Banking Sectors Financial Performance. Lp3M Stiebbank, 7(1), 43-53.

Sardo, F., \& Serrasqueiro, Z. (2018). Intellectual capital, growth opportunities, and financial performance in European firms: Dynamic panel data analysis. Journal of Intellectual Capital, 19(4), 747-767. https://doi.org/10.1108/JIC-07-2017-0099

Sawarjuwono, T. (2003). Intelektual Capital : Perlakuan, Pengukuran dan Pelaporan.

Sugiyono. (2018). Metode Penelitian Bisnis. Alfabeta.

Tan, H. P., Plowman, D., \& Hancock, P. (2007). Intellectual capital and financial returns of companies. Journal of Intellectual Capital, 8(1), 76-95. https://doi.org/10.1108/14691930710715079

Tran, D. B., \& Vo, D. H. (2018). Should bankers be concerned with Intellectual capital? A study of the Thai banking sector. Journal of Intellectual Capital, 19(5), 897-914.

https://doi.org/10.1108/JIC-12-2017-0185

Tran, N. P., \& Vo, D. H. (2020). Do banks accumulate a higher level of intellectual capital ? Evidence from an emerging market. https://doi.org/10.1108/JIC-03-2020-0097

Ulum, I. (2009). Intellectual Capital (Edisi Pert). Graha Ilmu.

Williams, S. M. (2003). Is Intellectual Capital Performance and Disclosure. Journal of Intellectual Capital, 2(3), 192-203. https://www.emerald.com/insight/content/doi/10.1108/14691930110399932/full/html

Zéghal, D., \& Maaloul, A. (2010). Analyzing value-added as an indicator of intellectual capital and its consequences on company performance. Journal of Intellectual Capital, 11(1), 39-60. https://doi.org/10.1108/14691931011013325 